\title{
The One Belt One Road Initiative as a New Silk Road: The (Potential) Place of Ukraine
}

\author{
Leonid L. Kyianytsia \\ Ph.D. in Political Science, National Aviation University (Kyiv, Ukraine) \\ E-mail: phukidides@gmail.com \\ https://orcid.org/0000-0002-0588-965X
}

This article provides an overview of the One Belt, One Road (OBOR) as a continental infrastructural integration project driven by geo-economic, and potentially geopolitical, interests of the People's Republic of China, with a view to both setting out the broad perspective on the project's significance for the future of Eurasian economic and infrastructural integration and positing Ukraine's potential place in this process. Based on the aforementioned analysis, the author presents an argument in favor of a cautious and considerate approach on the part of Ukraine's policy actors in so far as balancing the opportunities for restoring Ukraine's potential as a transit state with the country's commitments to its Euro-Atlantic partners may be concerned.

Keywords: integration, China, Eurasia, One Road One Belt, Ukraine

Received: April 15, 2019; accepted: April 24, 2019

Ukrainian Policymaker, Volume 4, 2019: 21-26.

https://doi.org/10.29202/up/4/3

\section{Introduction}

The problem of defining the scope and the directions of contemporary international integration processes would often present a veritable conundrum for the policy actors and researchers alike, since the development of such integration projects may start in one functional area (e.g. militarypolitical or financial-economic integration), only to acquire a more comprehensive (overarching) scope and objectives later. While the previous remark may most notably apply to the cases of the NATO and the EU respectively, the larger pattern the latter may be representative of could be extended to refer to other major integration processes as well. In this context, the case of the so-called One Belt One Road Initiative (hereinafter referred to as the OBOR) may be seen as potentially subject to the aforementioned logic, especially as the suspicions mount that China's high-profile project for logistical, financial, and trade integration throughout Eurasia is likely to have tangible international security implications [e.g. Wang et al., 2017; Liu, 2017].

Nevertheless, the political dimension of the OBOR should not distract one from considering the sheer fact of its emphasis on forging a geo-economic constellation providing for China's

(C) Kyianytsia, Leonid L., 2019 
leading role in greater Eurasia. In the course of such aspirations, the OBOR is likely to involve a number of nation-states that dispose of sizable continental transit potential along the respective routes. Given Ukraine's reputation for being plausibly one of greater Eurasia's most promising transit corridors [Ministry of Infrastructure of Ukraine, 2018: 3-4], it would be worth exploring the potential role to be played by Ukraine in the context of the OBOR initiative, while further accounting for the possible obstacles and undesirable side effects of Ukraine's involvement in such integration project. In doing so, a discussion of the main aspects and implications of OBOR as such may be combined with the thematic analysis of Ukraine's attitude toward the project in connection, so as to be able to arrive at a provisional balance of pros and cons as far as Ukraine's potential place in the OBOR may be concerned.

\section{The OBOR as a project for China-led Eurasian integration: an overview}

The rise of the People's Republic of China as one of the leading players in the global economy and simultaneously as an emerging power in terms of its geo-political and military-political relevance would be accompanied with the PRC leadership's growing interest in institutionalizing the projection of its economic power across the continent of Eurasia as the latter's most evident arena. Thus the 2013 announcement of the Chinese government's intent to invest heavily in developing a new transportation and logistics network for Eurasia in close cooperation with the governments of nations ranging from Central Asia to West Europe would reflect a new assertiveness of the Chinese leadership with respect to furthering China's commercial and diplomatic goals for the continent [Swaine, 2015: 4]. The perceptions of the OBOR project on the part of the Chinese policy makers and researchers themselves would largely amount to affirming the former's status as "a masterstroke of deepening China's reform and opening up and furthering peripheral diplomacy" [Lim, 2016: 115]. In such manner, the OBOR could be viewed as reflecting the Chinese diplomacy's predilection for creating and maintaining the pragmatically substantiated connections with miscellaneous countries of Eurasia on the basis of allegedly shared economic interests, rather than that of any 'grand' political and/or ideological narratives.

Conceptually, the OBOR is frequently referred to as the 'New Silk Road', thereby underscoring the former's perceived tie to the historical network of prestigious goods-carrying caravan roads having spanned the whole of Eurasia in the late $1^{\text {st }}$ millennium BCE to the mid- $2^{\text {nd }}$ millennium CE [Tweed, 2019; Tan, 2016]. The fact that OBOR would incorporate two major components, viz. (1) the 'One Belt' land route running from China to Turkey to Russia to the Netherlands and (2) the 'One Road' sea route meandering along the coasts of the South China Sea and the Indian Ocean up to Kenya's coasts (see Figure 1), could further connect its strategic sketch to that of both the 'overland' and the 'maritime' Silk Roads of the 1400s [Tan, 2016]. The effective makeup of the infrastructural projects to be implemented in the light of the OBOR's strategic objectives might thus parallel the historical legacy of the trade communities of the past. 


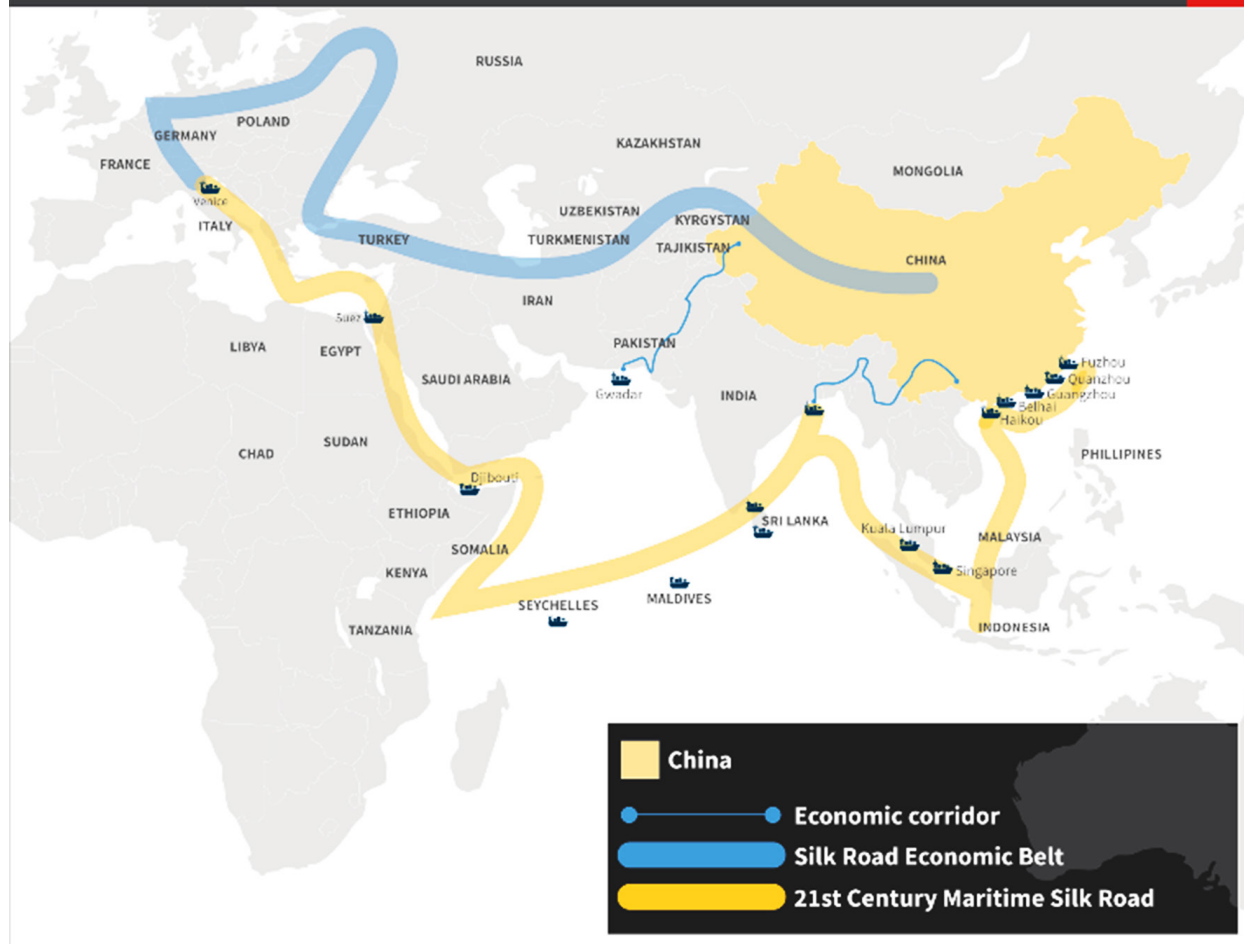

Figure 1. The OBOR's main routes, overland and maritime [Cai, 2017].

However, the OBOR is something more than mere reflection of the historical nostalgia as even the most passing look at the initiative's components would enable one to grasp its embeddedness in the strategic interests of the Chinese developmental state seeking to export its model of socio-economic development around Eurasia [Chan, 2018; Zhang, 2017]. The hypothesis as to the OBOR representing a possible attempt at complementing the development of alternative international economic institutions (including the New Development Bank, the Silk Road Fund, and the Asian Infrastructure Investment Bank (AIIB); Wong et al., 2017) appears to be rather far-fetched, yet it is clear that the United States and, to a certain extent, the European Union are nowadays prone to regard the OBOR as a potential threat to the extant global order at large and the balance of power in Eurasia in particular [Chatzky \& McBride, 2019; García-Herrero \& Xu, 2019]. It is still the fact that some EU member states, most notably, Italy under the M5S-La Lega coalition government, would countenance the possibility of joining at least some of the projects already being developed within the framework of the OBOR (e.g. as regards Chinese firms' right of access to the ports of Trieste and Genoa; Horowitz, 2019). Hence, given the increased emphasis on the part of the United States as for the need to curb the growing geo-economic power of China, a nation-state's participation in the structures affiliated with international economic institutions hosted by China, as well as with the OBOR projects as such, may be perceived as a more or less deliberate affront to the U.S. global hegemony. 


\section{The OBOR and Ukraine: opportunities and risks}

With this in mind, the possible participation of Ukraine in the OBOR initiative for continental infrastructural integration may present both challenges and opportunities, considering that the potential of Ukraine as a transit state may be revived by it being open to cooperation with Chinese interests within the context of the OBOR, whereas the geopolitical dimension of the 'New Silk Road' as a projection of China's infrastructural and economic power would make Ukraine's participation objectionable in the light of the nation's special relationship with the West. Thus these two factors provide for a rather complex milieu within which the development of mutually beneficial international economic relationship with China would have to be juxtaposed against an equally valid concern of possibly losing confidence of the U.S. and its allies in regard of the latter's perception of the OBOR as part of China's geopolitical flexing of muscles. The perspective of the Ministry of Infrastructure of Ukraine on that subject matter is that "reallocation of freight transport modal share between Europe and China both on economic and environmental grounds" [Ministry of Infrastructure of Ukraine, 2018: 4] could be seen as indicative of the new economic corridor development, with both Ukraine's and China's interests involved. However, at the same time it is duly noted that Ukraine may not aspire to utilizing such corridor capacity in a proper way without first reforming its transit regimes and customs system [Ministry of Infrastructure of Ukraine, 2018], which would raise the issues of political will and/or expediency on the part of the Ukrainian leadership. The additional factor possibly favoring Ukraine's future participation in the OBOR-related project would be that of the country's position along the Trans-Caspian International Transport Route, which is scheduled to become one of the principal logistical corridors adjacent to the main direction of the 'One Belt' (see Figure 1; Emerging Europe, 2018; Ministry of Economic Development and Trade of Ukraine, 2019). Subsequently, as noted in the respective publication by Ukraine's Government Portal, "Ukraine is ready to offer cost-effective transport routes on the territory of Ukraine to connect China with the countries of Europe, and also to establish cooperation between enterprises of Ukraine and China, with the further sale of products in the markets of the EU" [Ministry of Economic Development and Trade of Ukraine, 2019]. Such an upbeat perspective on the future fortunes of Ukraine in the context of the OBOR, however, would run counter to the EU officials' negative assessment of the impact of the latter on the economic and infrastructural development of Central and Eastern Europe, including Ukraine proper. Thus, as observed by EU Enlargement Commissioner Johannes Hahn with regard to Bosnia and Herzegovina's bid to participate in energy projects affiliated with the OBOR, such a move would jeopardize the EU's relationship with the Balkans state, since the respective agreement with China would 'violate' the environment and subsidy-related directives of the EU itself [VOA, 2019]. Therefore, Ukraine's current readiness to endorse the OBOR as part of its projected policy to restore the status of the transit state that had been undermined in the wake of the undeclared war with the Russian Federation appears to be just as problematic as it is potentially promising.

\section{Conclusions}

That said, it would appear as though the perspective of Ukraine's policy makers on the OBOR would currently be more optimistic than pessimistic, as attested to by the relevant quotations from the sources affiliated with the Ministries of Infrastructure and of Economic Development and Trade of Ukraine. The appropriate focus on the effective fostering of ties with China in respect of the latter's infrastructural and financial projects of the continental 
scope is more than understandable in this regard. However, as noted above, both the U.S. and the current EU leadership would view the OBOR as a dangerous challenge to the West's commercial and infrastructural development hegemony in Eurasia, the factor that would make it difficult to combine the pro-Western geopolitical orientation with the overtures toward China. Hence, the Ukrainian policy makers and governance stakeholders may be advised to become more specific as far as their geopolitical and geo-economic priorities may be involved, so as to avoid any inconsiderate steps that might alienate either side of the aforementioned international partnerships (and rivalries), as the case might be.

\section{References}

Cai, Peter. Understanding China's Belt and Road Initiative. Lowy Institute, 2017. https://www. lowyinstitute.org/publications/understanding-belt-and-road-initiative

Chan, Gerald. Understanding China's new diplomacy: Silk roads and bullet trains. Chichester: Edward Elgar Publishing, 2018.

Chatzky, Andrew, McBride, James. China's massive Belt and Road Initiative. Council on Foreign Relations, 2019. https:/www.cfr.org/backgrounder/chinas-massive-belt-androad-initiative

Emerging Europe. Bulgaria: The New Silk Road's gateway to Europe? https://emerging-europe. $\mathrm{com} /$ news/bulgaria-new-silk-roads-gateway-europe

García-Herrero, Alicia, and Jianwei Xu. The next step of the Belt and Road Initiative: Multilateralisation with Chinese characteristics. The Bruegel, 2019. http://bruegel. org/2019/04/the-next-step-of-the-belt-and-road-initiative-multilateralisation-withchinese-characteristics

Horowitz, Jason. Italy's deal with China signals a shift as U.S. influence recedes. The New York Times, 30 March 2019. https://www.nytimes.com/2019/03/30/world/europe/italy-onebelt-one-road-china.html

Lim, Wen Xin. China's One Belt One Road Initiative: A literature review. InTai Wei Lim, Wen Xin Lim, Katherine Tseng Hui-Yi, and Henry Chan Hing Lee (eds.). China's One Belt One Road Initiative. London: Imperial College Press, 2016: 113-132.

Liu, Zuokui. Europe and the "Belt and Road" initiative: Responses and risks. Beijing, China Social Sciences Press, 2017.

Ministry of Economic Development and Trade of Ukraine. Stepan Kubiv offered to create a logistics corridor China-Ukraine-EU through Ukraine. Government Portal, 2018. https://www.kmu.gov.ua/en/news/stepan-kubiv-zaproponuvav-stvoriti-cherez-ukrayinulogistichnij-koridor-kitaj-ukrayina-yes

Ministry of Infrastructure of Ukraine. A Look at Transit Transport in Ukraine. https://mtu.gov. ua/files/A\%20look\%20at\%20Transit\%20Transport\%20in\%20Ukraine-Draft-FinalReport.pdf

Swaine, Michael D. Chinese views and commentary on the "One Belt, One Road" initiative. China Leadership Monitor, No. 47, 2015: 1-24.

Tan, Ta Sen. Introduction of the Overland Silk Road and Maritime Silk Road. In Tai Wei Lim, Wen Xin Lim, Katherine Tseng Hui-Yi, and Henry Chan Hing Lee (eds.). China's One Belt One Road Initiative. London, Imperial College Press, 2016: 21-30.

Tweed, David. Quicktake: China's New Silk Road. Bloomberg News, 2019. https://www. bloomberg.com/quicktake/china-s-silk-road 
VOA. China's spreading influence in Eastern Europe worries West. https://www.voanews. com/a/chinese-eastern-europe/4871112.html

Wang, Xieshu, Joel Ruet, and Xavier Richer. One Belt One Road and the reconfiguration of China-EU relations. CNRS UMR, No. 7234, 2017: 1-17.

Wong, Erebus, Kin Chi Lau, Tsui Sit, and Tienjun Wen. One Belt, One Road: China's strategy for a new global financial order. Monthly Review, January 2017. https://monthlyreview. org/2017/01/01/one-belt-one-road

Zhang, Xin. Chinese capitalism and the Maritime Silk Road: A world-systems perspective. Geopolitics, Vol. 22, No. 2, 2017: 310-331. https://doi.org/10.1080/14650045.2017.12 89371 